\title{
The simulated response of dimethylsulfide production in the Arctic Ocean to global warming
}

\author{
By AlBERT J. GABRIC ${ }^{1 *}$, BO QU ${ }^{1}$, PATRICIA MATRAI ${ }^{2}$ and ANTHONY C. HIRST ${ }^{3}$, \\ ${ }^{1}$ School of Australian Environmental Studies, Griffith University, Nathan, 4111, Australia; ${ }^{2}$ Bigelow Laboratory for \\ Marine Sciences, 180 McKown Point, West Boothbay Harbor, ME 04575-475, USA; ${ }^{3}$ CSIRO Atmospheric Research, \\ Private Bag 1, Aspendale, 3195, Australia
}

(Manuscript received 16 December 2004; in final form 9 May 2005)

\begin{abstract}
Sulfate aerosols (of both biogenic and anthropogenic origin) play a key role in the Earth's radiation balance both directly through scattering and absorption of solar and terrestrial radiation, and indirectly by modifying cloud microphysical properties. However, the uncertainties associated with radiative forcing of climate due to aerosols substantially exceed those associated with the greenhouse gases. The major source of sulfate aerosols in the remote marine atmosphere is the biogenic compound dimethylsulfide (DMS), which is ubiquitous in the world's oceans and is synthesized by plankton. Climate models point to significant future changes in sea-ice cover in the Arctic Ocean due to warming. This will have consequences for primary production and the sea-to-air flux of a number of biogenic compounds, including DMS. In this paper we discuss the impact of warming on the future production of DMS in the Arctic Ocean. A DMS production model has been calibrated to current climate conditions with satellite ocean colour data (SeaWiFS) using a genetic algorithm, an efficient non-derivative based optimization technique. We use the CSIRO Mk 2 climate model to force the DMS model under enhanced greenhouse climate conditions. We discuss the simulated change in DMS flux and its consequences for future aerosol production and the radiative budget of the Arctic. Significant decreases in sea-ice cover (by $18.5 \%$ annually and $61 \%$ in summer-autumn), increases in mean annual sea surface temperature of $1{ }^{\circ} \mathrm{C}$, and a decrease of mixed layer depth by $13 \%$ annually are predicted to result in annual DMS flux increases of over $80 \%$ by the time of equivalent $\mathrm{CO}_{2}$ tripling (2080). Estimates of the impact of this increase in DMS emissions suggest significant changes to summer aerosol concentrations and the radiative balance in the Arctic region.
\end{abstract}

\section{Introduction}

Global climate is intimately connected to variability in the polar oceans. One of the strongest high-latitude feedbacks is thought to be the ice-albedo feedback mechanism, in which a positive temperature perturbation will melt sea ice, thus lowering the surface albedo, increasing the absorbed solar radiation and causing a further temperature increase. This positive feedback on warming leads global climate models to find enhanced warming in the Northern Hemisphere polar regions in transient simulations with increasing atmospheric greenhouse gases (Houghton et al., 1996, 2001). Because of these unique feedbacks, the Arctic may provide an early warning system for climate change (Comiso and Parkinson, 2004).

Dimethylsulfide (DMS) represents $95 \%$ of the natural marine flux of sulfur gases to the atmosphere, and it has been estimated that the flux of marine DMS supplies about $50 \%$ of the global

\footnotetext{
* Corresponding author.

e-mail: a.gabric@griffith.edu.au
}

biogenic source of sulfur to the atmosphere (Bates et al., 1992; Liss et al., 1997). After ventilation to the atmosphere, DMS is oxidized to form non-sea-salt sulfate (nss- $\mathrm{SO}_{4}^{2-}$ ) and methanesulfonic acid (MSA) aerosols and is the major source of cloud condensation nuclei $(\mathrm{CCN})$ in unpolluted marine atmospheres such as the Southern Ocean (Ayers and Gras, 1991). Sulfate aerosols formed from the oxidation of DMS can exert a climate cooling effect by scattering and absorbing incoming solar radiation and promoting the formation of $\mathrm{CCN}$ and brighter clouds (Charlson et al., 1987). A possible increase in DMS production is particularly important in the radiative budget of the Arctic, where surface albedo is otherwise predicted to decline due to a decreasing trend in both area and thickness of sea-ice cover (Parkinson and Cavalieri, 2002). With less sea ice, there is more open water, a potential for higher local DMS production and thus increased sulfate aerosols and CCN, with these effects combining to counter the initial loss of surface albedo.

The area-weighted summer and winter fluxes of DMS from the Arctic Polar Ocean to the atmosphere have been estimated to be 2.0 and $0.03 \mu \mathrm{mol} \mathrm{m}{ }^{-2} \mathrm{~d}^{-1}$, respectively (Leck and Persson, 
1996a). MSA is formed solely from DMS, unlike nss- $\mathrm{SO}_{4}^{2-}$ which also has anthropogenic sources. The MSA:nss- $\mathrm{SO}_{4}^{2-}$ ratio is indicative of the importance of DMS in sulfate aerosol production relative to other sources. This summer dominance of the biogenic sulfate source was confirmed by a 3-yr time-series collected by Quinn et al. (2002) in the Alaskan Arctic, who reported monthly mean MSA:nss- $\mathrm{SO}_{4}^{2-}$ ratios during the vernal peak at Alert and Barrow of $0.02 \pm 0.02$ and $0.08 \pm 0.09$, respectively. During the second summer peak, which occurs when anthropogenic nss- $\mathrm{SO}_{4}^{2-}$ concentrations are expected to be lower, monthly mean ratios were $0.17 \pm 0.19$ and $0.18 \pm 0.08$ at Alert and Barrow, respectively.

The total emission of marine biogenic sulfur from the Northern Hemisphere high latitudes $\left(60-90^{\circ} \mathrm{N}\right)$ is currently estimated to be about $36 \mathrm{Gmol} \mathrm{yr}^{-1}$, about $8 \%$ of the global total (Kettle and Andreae, 2000). Recent model projections of the impact of warming on the global zonal mean DMS flux $\left(70^{\circ} \mathrm{N}-70^{\circ} \mathrm{S}\right)$ indicate the greatest perturbation to be at high latitudes in both hemispheres, with little change predicted in the tropics and subtropics (Gabric et al., 2004). The predicted DMS flux perturbation at polar latitudes is due to a combination of factors, principal amongst which are a shoaling of the ocean mixed layer depth (MLD) and a decrease in the extent of sea ice. We note that the increased production of melt water will affect the MLD, so that these factors are not independent. Overall, these results point to the need for a detailed analysis of the DMS cycle in the Arctic Ocean, north of $70^{\circ} \mathrm{N}$.

The main biogenic source of dissolved DMS is through extracellular transformation of the precursor compound dimethylsulfoniopropionate (DMSP), which is synthesized in the cells of various phytoplankton species (Keller et al., 1989). In the Arctic, the composition of the phytoplankton community is heterogeneous, with a recent study reporting over 219 species in the central Barents Sea (Rat'kova and Wassmann, 2002). While polar phytoplankton species have been shown to be strong producers of DMSP, not all species produce vast quantities of DMS. However, even small DMS and DMSP producers, such as diatoms, when present in large abundance, will represent a large pool of DMS and DMSP. Furthermore, many phytoplankton species release their DMSP and DMS cellular pools, or make them available for bacterial transformation, only at the mature (late) stage of the bloom (Matrai and Vernet, 1997) or during enhanced grazing events that are also linked to the stage of the algal bloom.

In the Arctic, diatoms can be the dominant phytoplankton group for long periods of time, covering vast areas of open water, the marginal ice zone and under the ice; thus their pool of DMSP and resulting DMS is multiplied in space and time ultimately producing enough biogenic sulfur to significantly affect aerosols in the high Arctic (Leck and Persson, 1996a). In the Barents Sea region, plankton distribution and succession are especially complex due to the admixture of Atlantic and Arctic Ocean waters, and the seasonal change in sea-ice cover and wa- ter column stability that markedly influence both the algal and faunal composition.

Elevated concentrations of the prymnesiophytes Phaeocystis sp. and occasionally Emiliania huxleyi (both high DMSPproducing species) are known to occur in the Arctic Ocean, which can lead to the production of large quantities of DMS, just as icealgal communities are likely to be an important source of DMSP and DMS (Kirst et al., 1991; Bouillon et al., 2002). Although algal taxonomy is important to DMS production, it is not critical, as Matrai and Vernet (1997) found that in the Barents Sea the contribution of diatoms (not strong producers of DMSP or DMS in temperate waters) to the water column budgets of DMSP and DMS could be as significant as that of prymnesiophytes, and DMS cycling depended more on the stage of the bloom than algal taxonomy. Once DMSP is released from the phytoplankton cells into the surrounding sea water, algal and/or bacterial enzymes modulate its transformation to DMS and/or other compounds as part of a complex food web (Simó, 2001).

The summer Arctic aerosol composition was studied intensively during the International Arctic Ocean Expeditions in 1991, 1996 and 2001 (Leck et al., 1996; Leck and Persson, 1996b; Leck et al., 2004). Based on these observations, Leck and Bigg (1999) suggested that open ice leads were the dominant source for both large and small particles in the summer Arctic atmosphere. Analysis of air-parcel back-trajectories during field campaigns in 1991, 1996 and 2001 has shown instantaneous formation of new aerosols over the high Arctic during periods following residence of an air mass over the pack ice for several days, resulting in low or undetectable levels of atmospheric DMS and its oxidation products MSA and $\mathrm{SO}_{2}$; such residence would preclude a marginal ice zone source for the new particles. Such new particle events also occurred at times of very stable boundary layer conditions, thus blocking an upper troposphere, or higher, source. This leaves the open leads as a source with the particles identified as not only derived from DMS but also consisting of primary biological particles (organic aggregates, phytoplankton remains, bacteria) and primary biogenic submicrometre $\mathrm{CCN}$ with condensation of DMS oxidation products (Bigg and Leck, 2001; Bigg et al., 2004). During the summer, DMS-derived particles dominated the $\mathrm{CCN}$ population and mass for the most common wind speeds (Leck et al., 2002). The effect of changes in the extent of the marginal ice zone (MIZ) and the formation of new leads in areas which constitute permanent sea ice, have been proposed as critical for the future production of aerosol particles and CCN in the Arctic Ocean (Nilsson et al., 2001; Leck et al., 2002). This hypothesis has been confirmed by the analysis of ice-core data from the Svalbard glacier, where high MSA concentrations were found to be associated with warmer than average sea-surface temperatures and reduced extent of sea ice (O'Dwyer et al., 2000). The steadily decreasing rate of ice cover could also give rise to a more stratified euphotic zone, in already nutrient-rich waters, which would support a more pronounced spring bloom in the area (Olli et al., 2002) potentially resulting 
Table 1. Parameter values for the DMS model

\begin{tabular}{llll}
\hline Parameter & Process & Unit & Value \\
\hline$\mu_{0}$ & Maximum rate of N uptake by P & $\mathrm{d}^{-1}$ & 0.79 \\
$k_{\mathrm{s}}$ & Half-saturation constant for P & $\mathrm{mg}^{-} \mathrm{N} \mathrm{m}^{-2}$ & $311^{\mathrm{a}}$ \\
$k_{1}$ & Z grazing rate on P & $\left(\mathrm{mg}-\mathrm{N} \mathrm{m}^{-2}\right)^{-1} \mathrm{~d}^{-1}$ & 0.00052 \\
$k_{2}$ & Z specific N excretion rate & $\mathrm{d}^{-1}$ & 0.0039 \\
$k_{3}$ & N assimilation ratio for Z & - & 0.81 \\
$k_{4}$ & Release rate of DMSP by $\mathrm{P}^{\mathrm{b}}$ & $\mathrm{d}^{-1}$ & $0.01^{\mathrm{a}}$ \\
$k_{5}$ & Release rate of DMS by $\mathrm{P}^{\mathrm{b}}$ & $\mathrm{d}^{-1}$ & $0.0085^{\mathrm{a}}$ \\
$k_{6}$ & DMSP excretion rate by Z & $\mathrm{d}^{-1}$ & 0.01 \\
$k_{7}$ & DMSP-DMS conversion rate & $\mathrm{d}^{\mathrm{b}}$ & 0.28 \\
$k_{8}$ & DMSP microbial consumption rate & $\mathrm{d}^{-1}$ & 0.25 \\
$k_{9}$ & DMS microbial consumption rate & $\mathrm{d}^{-1}$ & 0.11 \\
$k_{10}$ & Maximum DMS photolysis rate & $\mathrm{d}^{-1}$ & 0.44 \\
$\gamma_{\text {max }}^{\mathrm{c}}$ & Max algal S(DMSP)/N ratio & 0.69 \\
$\mathrm{I}_{k}$ & Saturating light intensity for photosynthesis & $\mathrm{W} \mathrm{m}^{-2}$ & 3.03 \\
$N_{0}=P+Z+N$ & Total nutrient concentration & $\mathrm{mg}^{\mathrm{b}} \mathrm{N} \mathrm{m}^{-2}$ & 375.4 \\
\hline
\end{tabular}

${ }^{a}$ These parameters were based on existing data, and not varied in the calibration.

${ }^{\mathrm{b}}$ Indicates the sulfur-specific parameters.

${ }^{\mathrm{c}}$ In this study, the DMSP ratio $\gamma$ is the maximum annual value.

in enhanced sea-air DMS fluxes. Currently, the winter production of sea ice in the Arctic Ocean is high, which creates cold, high-salinity water that sinks and drives deep ocean circulation. If surface waters warm and sea ice does not form as well in winter, these processes involving salinity and circulation could be reduced or eliminated, having a significant further impact on global climate.

Here we simulate the cycle of DMS in the Barents Sea (30$\left.35^{\circ} \mathrm{E}, 70-80^{\circ} \mathrm{N}\right)$ region of the Arctic Ocean during the period (1998-2002) using a biogeochemical model that has been calibrated with current field and satellite data. We then use zonal average output from the CSIRO Mk2 atmosphere-ocean climate model (GCM) and zonal mean satellite chlorophyll data to force the DMS model, and simulate the perturbation to the sea-to-air flux of DMS under enhanced greenhouse conditions (baseline $1 \times \mathrm{CO}_{2}$ and equivalent tripled $\left.\mathrm{CO}_{2} 3 \times \mathrm{CO}_{2}\right)$ in the $70-80^{\circ} \mathrm{N}$ band.

\section{Methods}

\subsection{The DMS model}

The DMS model was originally described by Gabric et al. (1993) and is a nitrogen-based, depth-averaged (mixed-layer) model which is closed with respect to total nutrients. Versions of the model have been previously applied in the Barents Sea (Gabric et al., 1999) and in the Southern Ocean (Gabric et al., 1998, 2003). Cropp (2003) detailed the dynamics of the DMS model and analysed its equilibrium characteristics, showing that the original model food web (Gabric et al., 1993) could be simpli- fied to a phytoplankton-zooplankton-nitrate (PZN) web without major change in the DMS prediction. It should be noted that the original model had a modest microbial loop parametrization.

The nitrogen-based model used here includes three biotic state variables: generic phytoplankton $(P)$, zooplankton $(Z)$ and dissolved nitrate $(N)$. Total mass, $N_{0}$, is conserved in the mixed layer, i.e. detrital losses are assumed to be exactly balanced by re-injection of nutrients from below the pycnocline. All state variables are vertically averaged over the oceanic mixed layer, where the MLD can vary throughout the year as prescribed by the output from the GCM simulation. The food-web model includes five biological rate parameters, an available nutrient concentration and three parameters (see Table 1) describing the physical forcing on the phytoplankton growth rate:

$\frac{\mathrm{d} P}{\mathrm{~d} t}=\mu P-k_{1} P Z$

$\frac{\mathrm{d} Z}{\mathrm{~d} t}=k_{1}\left(1-k_{3}\right) P Z-k_{2} Z$

$\frac{\mathrm{d} N}{\mathrm{~d} t}=k_{1} k_{3} P Z+k_{2} Z-\mu P$

$N_{0}=P+Z+N$

The phytoplankton nitrate-specific growth rate, $\mu$ in eq. (2a), has been parametrized using the standard multiplicative form, with the growth contemporaneously limited by nutrient availability $\left(R_{\mathrm{N}}\right)$, light $\left(R_{\mathrm{L}}\right)$ and temperature $\left(R_{\mathrm{T}}\right)$ :

$\mu=\mu_{0} R_{\mathrm{N}} R_{\mathrm{L}} R_{\mathrm{T}}$ 
$R_{\mathrm{N}}=\frac{N}{N+k_{\mathrm{s}}}$

$R_{\mathrm{L}}=\left(\frac{I}{I_{k}}\right) / \sqrt{1+\left(I / I_{k}\right)^{2}}$

$R_{\mathrm{T}}=\mathrm{e}^{0.063\left(T-T_{\max }\right)}$

where each limitation coefficient is in the range $0<R_{i}<1$. The parameter $\mu_{0}$ is the maximum phytoplankton growth rate, $k_{\mathrm{s}}$ the nitrate half-saturation concentration, $I$ the mixed-layer mean photosynthetically available radiation (PAR) and $I_{k}$ the saturating irradiance (Talling, 1957). Laboratory culture studies on various algal species show a clear temperature effect (eq. 2d) on the growth rate of phytoplankton (Eppley, 1972), with $T_{\max }$ the maximum annual mixed layer temperature.

The DMS $(\mathrm{P})$ submodel is described by the following equations:

$\frac{\mathrm{dDMSP}}{\mathrm{d} t}=k_{4} \gamma P+k_{6} \gamma Z-k_{7} \mathrm{DMSP}-k_{8} \mathrm{DMSP}$

$\frac{\mathrm{dDMS}}{\mathrm{d} t}=k_{5} \gamma P+k_{7} \mathrm{DMSP}-k_{9} \mathrm{DMS}-k_{10} \mathrm{DMS}-k_{w} \mathrm{DMS}$

where DMSP and DMS concentrations are given as $\left(\mathrm{mg} \mathrm{S} \mathrm{m}^{-2}\right)$. In the light of recent results that indicate that the algal cell content of DMSP $(\gamma)$ varies seasonally and is sensitive to oxidative stressors such as incident radiation (Sunda et al., 2002), we have reformulated $\gamma$ to vary with time according to the following relation:

$\gamma(t)=\gamma_{\max }\left(I(t) / I_{\max }\right)+0.05$

where $I_{\max }$ is the maximum annual mixed layer PAR. The calibrated values of the model parameters are listed in Table 1.

As DMS is supersaturated in the surface ocean, the sea-to-air flux of DMS was computed as the product of the sea-to-air DMS transfer velocity and the sea-water DMS concentration:

$F_{\mathrm{DMS}}=k_{w}[\mathrm{DMS}]$

The transfer velocity $k_{w}\left(\mathrm{~cm} \mathrm{~h}^{-1}\right)$ was parametrized in terms of wind speed, $w$, and sea surface temperature (SST) according to the formulation of Liss and Merlivat (1986) as adapted for DMS by Gabric et al. (1995):

$k_{w}=\alpha 0.17 w \quad$ for $w \leq 3.6$

$k_{w}=\beta(2.85 w-10.3)+0.61 \alpha$ for $3.6<w \leq 13$

$k_{w}=\beta(5.9 w-49.9)+0.61 \alpha$ for $w>13$

with $\alpha=(600 / S c)^{2 / 3}$ and $\beta=(600 / S c)^{1 / 2}$. For a given gas, the Schmidt number $(S c)$ varies with water temperature, decreasing as the temperature increases. The dependence of the Schmidt number on sea surface temperature for DMS was experimentally derived by Saltzman et al. (1993) as

$S c=2674.0-147.12(\mathrm{SST})+3.726(\mathrm{SST})^{2}-0.038(\mathrm{SST})^{3}$.

We note that empirical gas exchange-wind speed relationships have to be applied with caution, since they have an uncertainty of up to a factor of 2 (Kettle and Andreae, 2000), with more recent parametrizations (Nightingale et al., 2000) predicting higher fluxes. The calculation of $k_{w}$ in the seasonal ice zone poses special difficulties since release of DMS from sea ice during melting or break-up is well documented (Curran and Jones, 2000; Trevena et al., 2003), and ice algae have also been shown to be significant producers of DMS and DMSP in the polar oceans (Kirst et al., 1991; Levasseur et al., 1994). We assume that DMS ventilation can only occur in ice-free waters, which is likely to be a lower bound on the true flux. Thus, the computed areal DMS flux was scaled by the fraction of ice-free water.

\subsection{Meteorological and satellite data}

The time-series of meteorological and satellite data were obtained from the following sources: surface wind speed (1998-1999) and SST (1998-2002) were obtained from Reynolds/NCEP in PO.DAAC Ocean ESIP Tool (POET) (http://podaac-esip.jpl.nasa.gov/poet/). Surface wind speed for the period 2000-2002 was available from QuickSCAT sensor data (http://podaac.jpl.nasa.gov/quikscat). Mixed-layer depth data were taken from the Levitus World Ocean Atlas (WOA94) based on the long-term monthly climatology. Sea-ice cover was derived from NCDC Special Sensor Microwave Imager (SSMI) satellite data for the period 1988-2002. The monthly cloud cover climatology ( $1^{\circ}$ resolution) was obtained from the ICOADS data set distributed by the Data Support Section, NCAR/SCD (http://www.dss.ucar.edu/datasets/ds540.1).

\subsection{DMS model calibration}

Model calibration in the Barents Sea study region proceeded in two stages, with the PZN submodel parameters estimated first using the SeaWIFS chlorophyll (CHL) data, followed by the sulfur submodel parameters using the DMSP field data. To obtain valid parameters for the GCM simulations, the entire process was repeated using zonal mean CHL data, and the zonal average meteorological forcings.

Parametric estimation for the calibration was done using a genetic algorithm (GA) which is an efficient, non-derivative-based optimization technique that mimics natural evolution (Holland, 1975). The PZN submodel parameters (Table 1) were calibrated against satellite CHL data derived from 5 yr of SeaWiFS (8-d) standard mapped images as a proxy for phytoplankton biomass (i.e. P). To estimate goodness-of-fit, Press et al. (1992) suggest minimizing a $\chi^{2}$ statistic when the standard deviations $\sigma_{i}$ of the 
data points, $y_{i}$ are not constant:

$\chi^{2}=\sum_{i=1}^{N}\left(\frac{y_{i}-y\left(t_{i}, \boldsymbol{k}\right)}{\sigma_{i}}\right)^{2}$

where $N$ is the number of data points ( $N=26$, as the CHL 8 -d satellite time-series was only available between polar sunrise and sunset) and $\boldsymbol{k}$ the vector of adjustable model parameters of size $M$ (=6 for CHL calibration). This statistic also allows an estimate of the statistical significance of the fit. A rule of thumb for a moderately good fit is a value of $\chi^{2}$ of $\sim(N-M)$ (Press et al., 1992).

During the CHL calibration, six PZN model parameters were varied (Table 1). Of these parameters, $I_{k}$ and $k_{1}$ were found to be the most sensitive. It was found that the smaller the $k_{1}$ value, the higher the $P$ bloom peak, while lower the saturating irradiance values $I_{k}$ caused an earlier bloom peak. The sulfur submodel was calibrated by varying only the five sulfur-specific parameters (Table 1). There are limited data on sulfur species in the Arctic Ocean (Kettle et al., 1999). Matrai and Vernet (1997) reported the first comprehensive study of DMS and DMSP cycling in the Barents Sea on a cruise during May 1993. Our previous modelling analysis in the Barents Sea, was based on this 1993 data set, and supplied initial estimates for the sulfur parameters (Gabric et al., 1999). More recently, four field cruises were conducted in the Barents Sea region during the period of satellite data capture: in March and May 1998, June-July 1999 and July 2001 (Rat'kova and Wassmann, 2002; Reigstad et al., 2002). Although DMS was not measured, the recent cruises did provide data on the precursor DMSP (Fig. 1) (P. A. Matrai, unpublished), which were used for the sulfur submodel calibration. The DMSP field data indicate marked annual and seasonal variability with elevated values (transect mean $\sim 34 \mathrm{nM}$ ) associated with the vernal bloom in May 1998, and then another very high peak during the summer of July 2001 (transect mean $\sim 46 \mathrm{nM}$ ).

\subsection{Climate change simulations}

The transient climate data were obtained from simulations with the Commonwealth Scientific and Industrial Research Organisation (CSIRO) coupled climate model (Gordon and O'Farrell, 1997) which includes ocean, atmosphere and sea-ice components. The horizontal resolution of the atmospheric model is 5.6 degrees of longitude by 3.2 degrees of latitude (strictly it is a spectral model of R21 resolution) and it has nine vertical levels. The sea-ice model was described in O'Farrell (1997). The ocean model is based on the Bryan-Cox code (Cox, 1984) with 21 vertical levels. Further details of the ocean component are given in Hirst et al. (2000).

The coupled GCM was initialized using the final spin-up state of the atmosphere-ocean system which resulted from several thousand years of integration. The control integration used a constant equivalent $\mathrm{CO}_{2}$ concentration of $330 \mathrm{ppm}$ and was used to evaluate the statistical significance of trends predicted in the transient integration. The transient integration is subject to changing equivalent $\mathrm{CO}_{2}$ concentration as specified in the IPCC/IS92a radiative forcing scenario following the prescription of Kattenberg et al. (1996) for the period from 1880 to 2086.

A subset of the output from GCM simulations for the periods 1961-1970 (baseline $1 \times \mathrm{CO}_{2}$ ), and 2078-2086 (tripled equivalent $\mathrm{CO}_{2} 3 \times \mathrm{CO}_{2}$ ) were obtained for the zonal area between

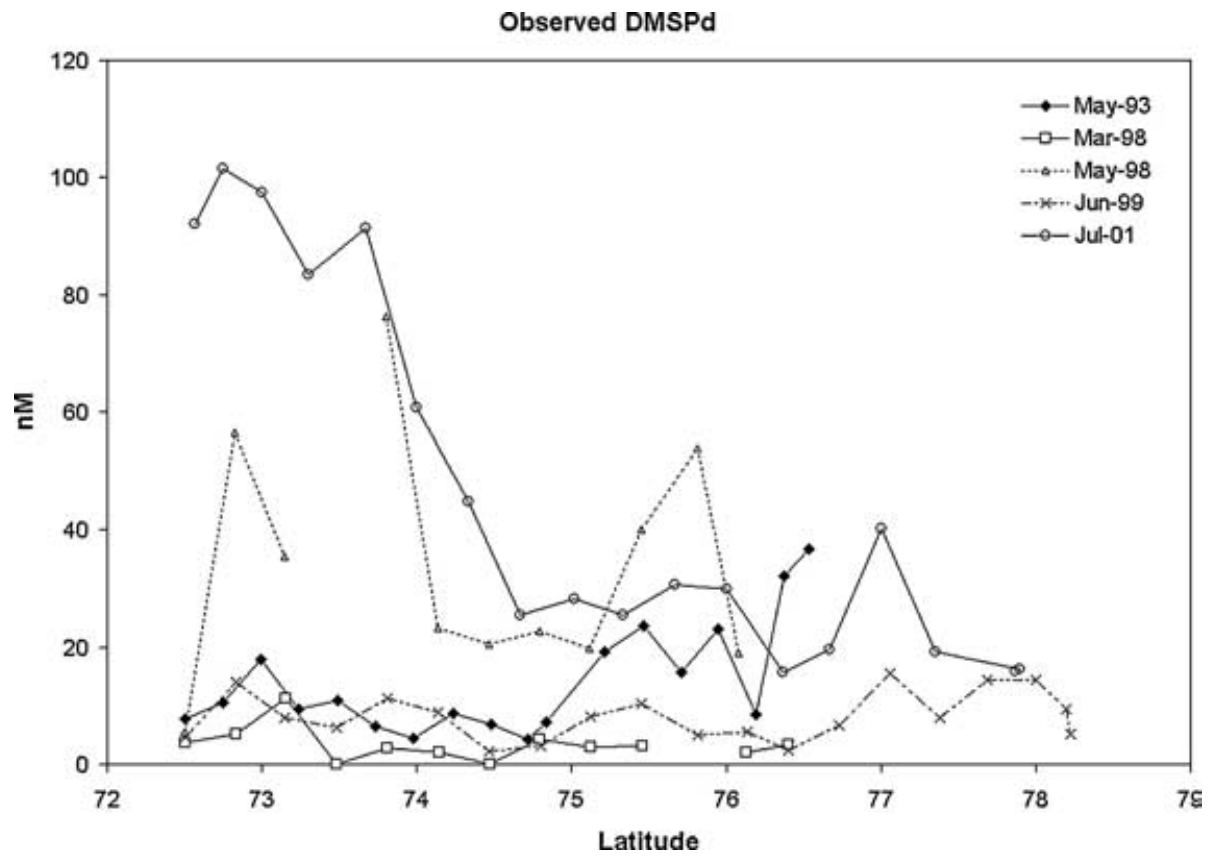

Fig 1. Observed values of dissolved DMSP along transects in the Barents Sea. 
70 and $80^{\circ} \mathrm{N}$. The GCM output data were temporally averaged to derive monthly means of SST, MLD, sea ice and cloud cover and daily averages of surface wind speed. The DMS model was then forced with the GCM data for baseline and $3 \times \mathrm{CO}_{2}$ climates and the perturbation in flux computed. As GCM output did not include irradiance in the photosynthetic range, and there was very little change in GCM-simulated short-wave radiation, the current PAR seasonal cycle was used with cloud cover changes as specified by the GCM.

\section{Results and discussion}

\subsection{CHL and DMS calibration results in the Barents Sea study region}

In our previous studies in the Antarctic Southern Ocean, the seasonal shallowing of MLD was found to be critical to phytoplankton growth and hence the DMS production rate (Gabric et al., 2003); however, the mean MLD in the Barents Sea is shallow all year round, ranging from about $40 \mathrm{~m}$ during winter to less than $5 \mathrm{~m}$ in July-August (Fig. 2a). SST displays an annual range of about $4^{\circ} \mathrm{C}$ (Fig. 2b). Mean winds are high during the winter season $\left(\sim 10 \mathrm{~m} \mathrm{~s}^{-1}\right)$, moderating in late summer (August) to $5.7 \mathrm{~m} \mathrm{~s}^{-1}$ (Fig. 1c). Sea-ice cover ranges from a maximum of $42 \%$ during January-May, to a minimum in August ( $1 \%)$; however, interannual variability was high (Fig. 2d). The sky was overcast for most of the year ( $\sim 6-7$ octas mean cloud cover).

Conditions in the Barents Sea during the spring of 1998 and summer of 1999 have been summarized by Reigstad et al. (2002).
Atlantic water dominated in the south separated by the Polar Front from water with more Arctic characteristics in the north. A high, uniform nutrient regime in March was depleted by May, giving a spring bloom with phytoplankton biomass concentrated in the upper $30 \mathrm{~m}$ in the strongly stratified marginal ice zone. The new primary production estimates for the period ranged from 30 $80 \mathrm{~g}-\mathrm{C} \mathrm{m}^{-2}$. Based on previous studies, the vernal bloom in the Barents Sea generally initiates in early April, with phytoplankton biomass gradually increasing to its peak around the end of April or early May, then decreasing from the middle of May. There is a second, much smaller, bloom in September, due presumably to the shallower MLD, warmer SST and reduced grazing pressure (Arashkevich et al., 2002). Detailed comparisons between field surface samples of CHL and the SeaWiFS satellite-derived data during the 1998-1999 cruises were given in Qu et al. (in press) and good agreement was evident at most stations.

Figure 3 shows the comparisons for the calibrated model results and the SeaWiFS data for the 5-yr period 1998-2002 between polar sunrise and sunset. The $\chi^{2}$ fitting function is computed by maximizing the negative value, hence the closer to zero the better the fit. A $\chi^{2}$ value of -4.4 was obtained for the 5-yr mean data, which based on the criterion noted above suggests a very good fit. Using the calibrated food web model, the annual cycle in DMS was then computed. The DMS concentrations increased after the polar sunrise with the first DMS peak occurring about $10 \mathrm{~d}$ after the CHL bloom peak. The second peak in DMS (due to excretion of DMSP and DMS by zooplankton grazing) occurs 2 months after the CHL spring bloom. Interestingly, the model predicts that the maximum DMS
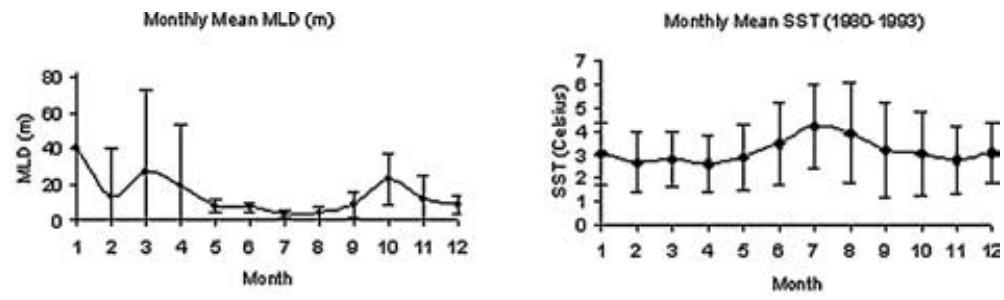

Monthly Mean Wind Speed (1900-1093)

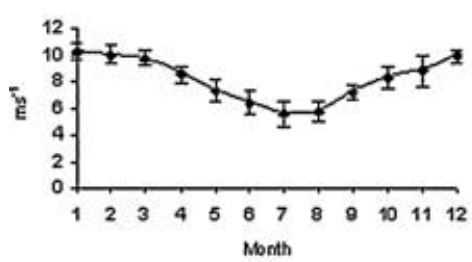

Monthly Mean Cloud Covet (1890-1003)

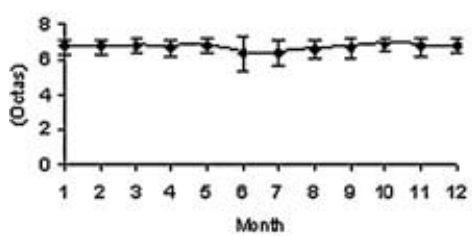

Ice cover (\%) (1988-2002)

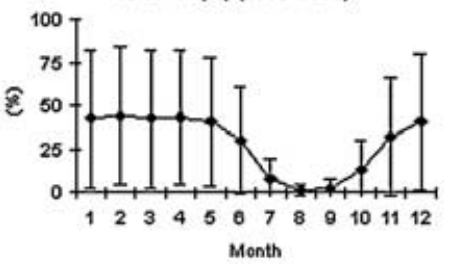

19082002 Mean PAR (19982002)

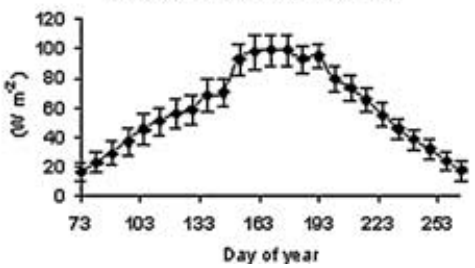

Fig 2. Annual cycles in current

meteorological forcings in the Barents Sea. 
(a) 1998-2002 CHL Calibration

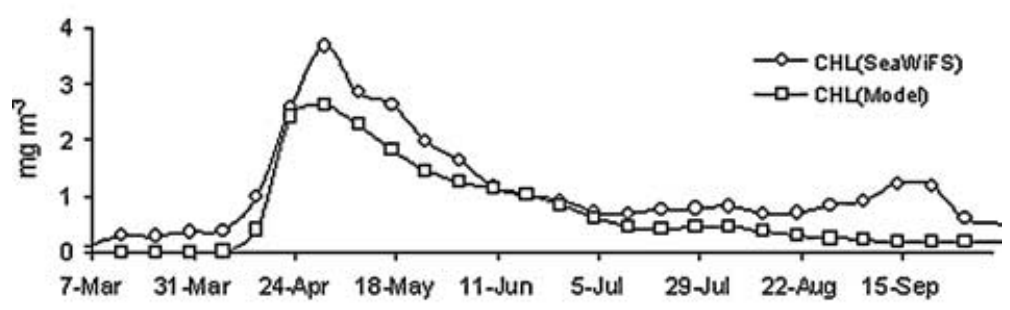

(b) Calibrated mean DMS cycle (1998-2002)

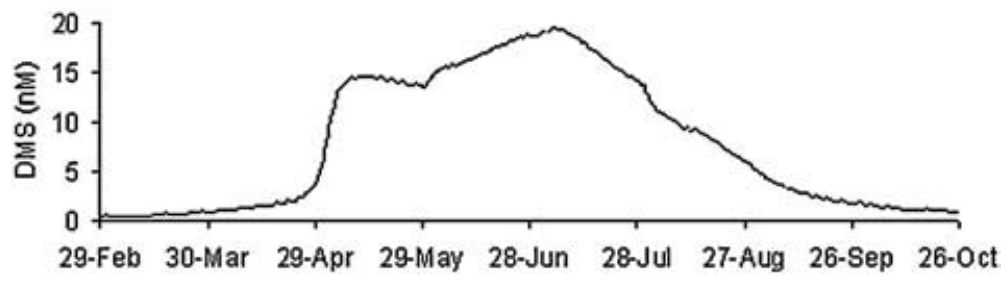

(c) Simulated annual DMS flux in ice free water (1998-2002)

Fig 3. Predicted cycles in (a) CHL , (b) DMS concentration and (c) DMS flux in the Barents Sea.

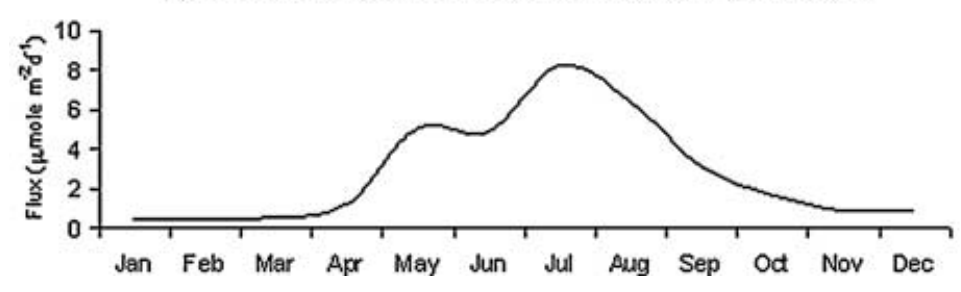

concentration will occur in the middle of July, when CHL concentrations are well below their peak spring values. This agrees with field observations of dominance of the plankton by flagellates (Rat'kova and Wassmann, 2002; Verity et al., 2002) of low CHL content, possibly heterotrophic and potentially a strong source of DMS/P. Measured DMSP values in midJuly 2001 were high, sometimes higher than spring concentrations (Fig. 1), thus providing a potentially large source of DMS.

\subsection{The seasonal cycle of DMS flux}

The predicted mean cycle in DMS flux in ice-free water is shown in Fig. 3. There are two distinct peaks in the DMS flux cycle. The double peak has also been noted in the database compiled by Kettle and Andreae (2000) in high and middle latitudes. This model prediction has been attributed to the combined effects of changes in wind speed, SST and MLD on the DMS flux (Gabric et al., 2003). In the Arctic region, the first peak in DMS flux was just a few days after the CHL spring bloom peak. The second flux peak occurred in July, about 2 months later, and might also be related to excretion of $\mathrm{DMS}(\mathrm{P})$ by grazers or a change in species composition of the plankton (Rat'kova and Wassmann, 2002).

\subsection{DMS flux perturbation under enhanced greenhouse conditions}

The forcing of the DMS model with output from the CSIRO Mk2 GCM model has previously been described by Gabric et al. (1998, 2003). The GCM data on SST, wind speed, MLD, sea ice and cloud cover were obtained for the period of 1960-1970 (baseline conditions $1 \times \mathrm{CO}_{2}$ ) and 2078-2086 (tripled equivalent $\mathrm{CO}_{2}: 3 \times \mathrm{CO}_{2}$ ). The $\mathrm{CHL}$ calibration was recomputed, now using the zonal mean CHL data from SeaWiFS. An excellent $\chi^{2}$ value $(-0.76)$ was obtained for the zonal mean CHL data calibration (Fig. 4). As no extra DMS(P) data were available, the previous sulfur submodel calibration was reused.

We note that the baseline $\left(1 \times \mathrm{CO}_{2}\right)$ zonal averaged GCM data (Fig. 5) display some significant differences to the current Barents Sea climate data (Fig. 2). For example, wind speeds are reduced and the MLD is deeper compared with the current data. Field SST is higher in the Barents Sea, presumably due to the regional influence of warm Atlantic inflows, which is not felt as strongly in other parts of the Arctic Ocean included in the $70-80^{\circ} \mathrm{N}$ zonal band. There is also a delay in the mean SST maximum from July (field) to September (GCM). This influence of warmer AW inflows also affects the sea-ice cycle in the Barents Sea, already experiencing an almost complete melting 


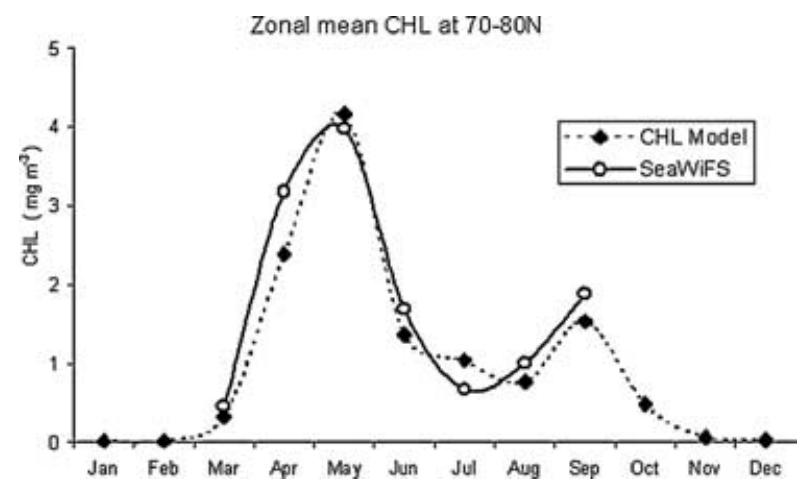

Fig 4. CHL calibration for the zonal band $70-80^{\circ} \mathrm{N}$.

of sea ice during late summer to early autumn; here, the $15-\mathrm{yr}$ field data set and the GCM baseline prediction show excellent agreement.

From the baseline level $\left(1 \times \mathrm{CO}_{2}\right)$ to tripled equivalent $\mathrm{CO}_{2}\left(3 \times \mathrm{CO}_{2}\right)$, the following changes in zonal mean forcings are simulated by the GCM: SST increases up to $2{ }^{\circ} \mathrm{C}$ in its peak month of September and by $0.5^{\circ} \mathrm{C}$ in April (Fig. 5a), the enhanced summer warming resulting from a decrease in albedo due to sea-ice loss, during the August to October period (Fig. 5b). The predicted disappearance of summer sea ice under warming is consistent with results of other climate change simulations (Johannssen et al., 2004). However, climate model intercomparison studies have noted that there is a large range in the simulated response of sea ice to warming, with no obvious relation to the sea-ice model attributes (Flato, 2004). It is important to note that Arctic sea ice in the CSIRO Mk 2 control run is generally thinner than observed, and the rate of warming overall a little more rapid than the mean rate of warming seen in other climate models.

The MLD decreases by $6.5 \mathrm{~m}$ on average, with the largest decreases $(-20 \%)$ occurring during spring and early summer. Wind speed and cloud cover (not shown) are not simulated to change significantly. The net impact on the DMS transfer velocity is slight, with a small increase during late summer as

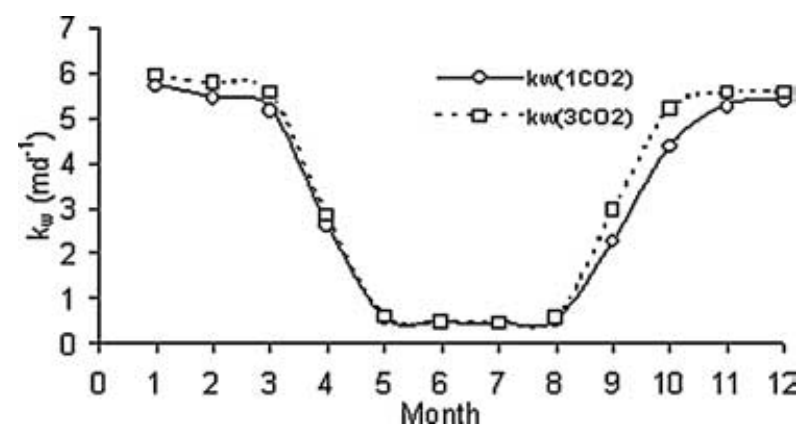

Fig 6. Change in the DMS transfer velocity $k_{w}$ under warming.

shown in Fig. 6. We note that Simó and Pedrós-Alió (1999) derived an empirical relationship that predicts surface DMS concentration to vary directly, but weakly, with chlorophyll $a$ and inversely with MLD. This relationship suggests a cancelling effect in May when maximum CHL concentrations imply a higher DMS level, while a deeper MLD may lead to lower DMS levels. Conversely, the combination of enhanced stratification and a second CHL peak in September should lead to enhanced DMS concentrations. Indeed, DMS flux is simulated to increase from June to November, with the peak monthly mean value of $1.8 \mu \mathrm{mol} \mathrm{m} \mathrm{m}^{-2} \mathrm{~d}^{-1}$ in September (Fig. 7), largely due to the increased fraction of ice-free ocean. The annual integrated DMS flux is predicted to increase by $86 \%$ (from 94.4 to $175.6 \mu \mathrm{mol} \mathrm{m}^{-2}$ ) under $3 \times \mathrm{CO}_{2}$ conditions, with most of the extra sulfur released to the atmosphere in late summer and autumn.

\subsection{Consequences for regional radiative forcing}

It should be noted a priori that there are many uncertainties associated with estimating the influence of aerosols on climate (Haywood and Boucher, 2000). This is particularly so in the high Arctic, where several features of the interactions between clouds, aerosols and climate appear to be more complex than in other parts of the globe (Curry, 1995). (a)

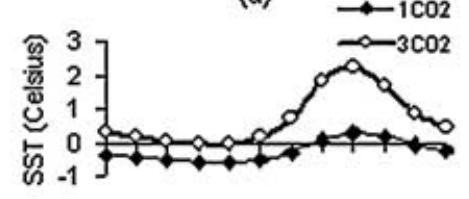

123456789101112

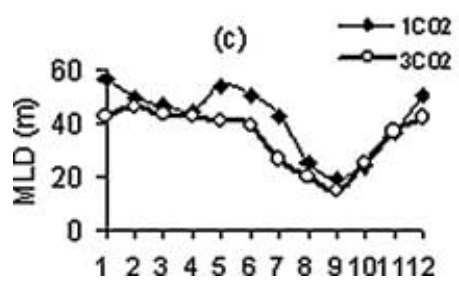

(b)

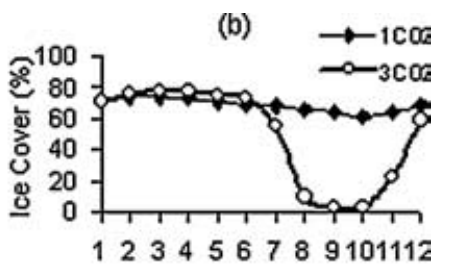

(d) $\underset{\rightarrow-3 \mathrm{co}}{\longrightarrow-1 \mathrm{co}}$

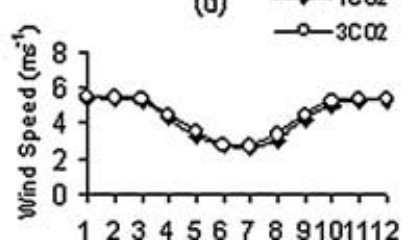

Fig 5. Changes in GCM simulated monthly mean (a) zonal SST, (b) ice cover, (c) MLD and (d) wind speed. 


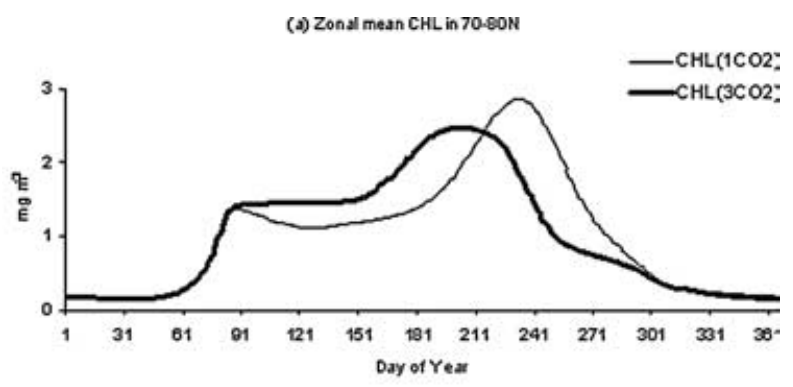

(b) Zonsi Mean DMS Flux Perturbtion in $70.8 \mathrm{cN}$

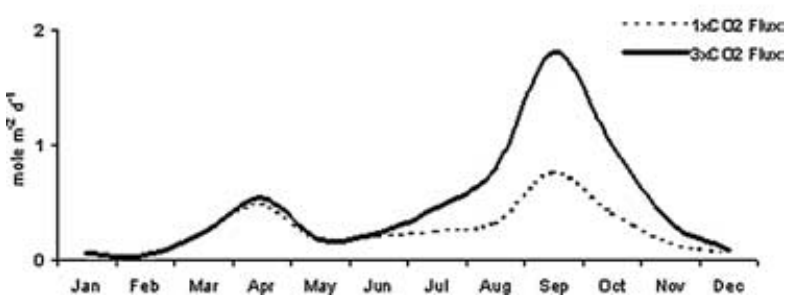

Fig 7. GCM simulated change in CHL cycle and DMS flux change under $3 \times \mathrm{CO}_{2}$ conditions.

Our simulation experiments suggests an annual increase in the DMS flux of about $86 \%$ under tripled equivalent $\mathrm{CO}_{2}$ for the high Arctic, with most of this increase being during the summer months (June-September). As noted earlier, field data indicate that the biogenic source of sulfate aerosol dominates only during summer, thus the following analysis applies only during this season.

As discussed by Charlson et al. (1987), DMS-derived sulfate aerosols have both a direct (backscatter) and an indirect (cloud albedo) effect on climate. Both these processes will depend on the change in sulfate aerosol concentration resulting from a change in DMS flux. We first discuss the indirect effect via a change in $\mathrm{CCN}$ concentration, and hence cloud albedo.

There have been several attempts to describe the dependence of CCN on DMS flux; however, to our knowledge no long-timeseries data exist for the high Arctic. Lawrence (1993) derived a generic empirical relation between DMS flux $\left(\mu \mathrm{mol} \mathrm{m}{ }^{-2}\right)$ and the concentration of $\mathrm{CCN}\left(\mathrm{cm}^{-3}\right)$ of the form

$\mathrm{CCN}=29 F_{\mathrm{DMS}}+45$.

Pandis et al. (1994) used a modelling approach to derive the following relationship for DMS flux values $>2.3 \mu \mathrm{mol} \mathrm{m}{ }^{-2}$, which corresponds to the lower bound of summer flux derived by Kettle and Andreae (2000) for the Arctic, using the conservative Liss and Merlivat parametrization:

$\mathrm{CCN}=22.7 F_{\mathrm{DMS}}-15$.

Using the measured monthly mean $\mathrm{CCN}$ data at Cape Grim (Tasmania) and estimates of mean monthly DMS flux, Gabric et al. (1998) derived the following relationships at $0.23 \%$ and
$0.47 \%$ supersaturation:

$\operatorname{CCN}(0.23)=8.4 F_{\mathrm{DMS}}+52$

$\operatorname{CCN}(0.47)=18.0 F_{\mathrm{DMS}}+57$.

These four equations provide a range on the simulated CCN enhancement for a given perturbation in DMS flux. Using a typical summer flux value of $\sim 5 \mu \mathrm{mol} \mathrm{m}{ }^{-2} \mathrm{~d}^{-1}$ for the high Arctic, then a $\Delta \mathrm{F}_{\mathrm{DMS}}$ of $+86 \%$ leads to relative $\mathrm{CCN}$ enhancements, $\Delta \mathrm{CCN} / \mathrm{CCN}$, in the range $0.38-0.99$ (median $=0.59$ ).

Following Charlson et al. (1992), the relative change in cloud optical depth $\delta_{\mathrm{c}}$ can be written as:

$\Delta \delta_{\mathrm{c}} / \delta_{\mathrm{c}}=\frac{1}{3}(\Delta \mathrm{CCN} / \mathrm{CCN})$

and the resulting perturbation to cloud-top albedo, $R_{\mathrm{c}}$, may be written as:

$\Delta R_{\mathrm{c}}=R_{\mathrm{c}}\left(1-R_{\mathrm{c}}\right)\left(\Delta \delta_{\mathrm{c}} / \delta_{\mathrm{c}}\right)$.

For a median $R_{\mathrm{c}}$ value of 0.65 (Dong and Mace, 2003) and the CCN enhancements given above, eqs (10a) and (10b) yield values for $\Delta R_{\mathrm{c}}$ in the range $0.029-0.075$. The perturbation in indirect radiative forcing resulting from a change in cloud-top albedo of marine stratus and stratocumulus clouds was given by Charlson et al. (1987) as

$\Delta F_{\mathrm{I}}=-(1 / 4) S A_{\mathrm{c}} \Delta R_{\mathrm{p}}$

where $S$ is the solar constant $\left(1370 \mathrm{~W} \mathrm{~m}^{-2}\right)$, and $\Delta R_{\mathrm{p}}$ is the change in planetary or top-of-atmosphere albedo, which may be calculated from the change in cloud-top albedo by $\Delta R_{\mathrm{p}}=$ $0.8 \Delta R_{\mathrm{c}}$. The factor $A_{\mathrm{c}}$ represents the fraction of the Arctic Ocean covered by stratiform cloud during summer (approximately 0.6 ) (Fig. 1). For the median CCN enhancement of 0.59, eq. (10b) gives the change in cloud-top albedo $\Delta R_{\mathrm{c}}(=0.045)$, from which $\Delta R_{\mathrm{p}}$ is computed to be 0.035 . Thus the median perturbation in indirect forcing is estimated to be $-7.3 \mathrm{~W} \mathrm{~m}^{-2}$.

We now compute the resulting effect on direct radiative forcing. Following the prescription given by Charlson et al. (1992), the perturbation to the direct radiative forcing due to an increase in aerosol concentration is given by

$\Delta F_{\mathrm{D}}=-(1 / 4) S\left(1-A_{\mathrm{c}}\right) \Delta R_{\mathrm{p}}$

where the resulting change to planetary albedo due to a change in aerosol concentration is given by

$\Delta R_{\mathrm{p}}=2 \tau^{2}\left(1-R_{\mathrm{s}}\right)^{2} \beta \Delta \delta_{\mathrm{a}}$.

Here $\tau$ is the fraction of incident radiation transmitted by the atmospheric layer above the aerosol $(0.76), R_{\mathrm{s}}$ is the mean ocean surface albedo, which will depend on the open water:sea-ice ratio during summer $(\sim 0.5)$ (Tschudi et al., 2001), $\beta$ is the fraction of radiation scattered upward by the aerosol $(0.29)$ and $\delta_{\mathrm{a}}$ is the aerosol optical depth over the ocean during summer $(\sim 0.05)$ (Treffeisen et al., 2004). 
Equation (12b) states that a perturbation in direct forcing will be related linearly to a perturbation in $\delta_{\mathrm{a}}$. A change in $\delta_{\mathrm{a}}$ is related to the perturbation in mean column burden of sulfate aerosol. If we assume this to be linear in condensation nuclei $(\mathrm{CN})$ concentration, and that $\mathrm{CN}$ and $\mathrm{CCN}$ concentrations are also linearly related (Lawrence, 1993), then $\Delta F_{\mathrm{D}}$ can be calculated from the $\mathrm{CCN}$ enhancements given above. Thus, for a median relative $\mathrm{CCN}$ enhancement of 0.59 , the perturbation in direct forcing is estimated to be $-0.27 \mathrm{~W} \mathrm{~m}^{-2}$.

The total perturbation to radiative forcing associated with the median $+5 \%$ change in DMS flux is thus estimated to be $-7.6 \mathrm{~W} \mathrm{~m}^{-2}$. The uncertainty in this radiative forcing can be estimated by first calculating upper and lower bounds on the $\mathrm{CCN}$ enhancements (eqs. 9a-d) and then recomputing ranges for both $\Delta \mathrm{F}_{\mathrm{D}}\left(-0.17\right.$ to $\left.-0.45 \mathrm{~W} \mathrm{~m}^{-2}\right)$ and $\Delta F_{\mathrm{I}}\left(-4.7\right.$ to $\left.-12.3 \mathrm{~W} \mathrm{~m}^{-2}\right)$. The resulting lower and upper bounds on the total perturbation to radiative forcing are $-4.9 \mathrm{~W} \mathrm{~m}^{-2}$ and $-12.8 \mathrm{~W} \mathrm{~m}^{-2}$, respectively.

\subsection{Potential for structural change of the food web}

The connection between climate change and structural changes to the ecosystem in the Arctic Ocean is important for understanding both past and future global climate change. The modelled change in DMS flux that we have described above is largely the result of physical changes in the water column. However, global warming has the potential to induce ecological shifts, the key question being whether this will enhance or mitigate the impact of the GCM-simulated physical changes on DMS production?

Current opinion is that global warming will expose the present southern seasonal ice zone to increased radiation and vertical mixing (Slagstad and Wassmann, 1997). Rat'kova and Wassmann (2002) suggest that under warming, the influence of Atlantic water may spread northwards. Recent observational evidence supports this theory, with Atlantic waters increasing their impact on the Arctic Ocean (Serreze et al., 2000). At present, the ratio of large (e.g. diatoms) to small-celled phytoplankton (e.g. prymnesiophytes) changes dramatically between ice-free and ice-covered regions in the Barents Sea, with large-celled species dominating the ice-covered area (Hansen et al., 1996). The "Atlantification" of the Arctic seasonal sea-ice zone may result in significant changes in biomass, seasonal variation and spatial distribution of phytoplankton. For example, there has been some evidence for an increasing incidence of coccolithophore blooms in the Arctic (Merico et al., 2003; Smyth et al., 2004). The coccolithophore E. huxleyi, which is found in the North Atlantic, can form dense blooms with cell counts $>10^{6}$ cells $1^{-1}$ and contains high but variable amounts of cellular DMSP (Matrai and Keller, 1993). With a decrease in the extent of the MIZ, the relative biomass of large- to small-celled phytoplankton species may decrease under warming. A floristic shift in algal species that alters the relative proportions of diatoms (generally low intracellular DMSP) to Phaeocystis pouchetii is likely to have a sig- nificant impact on both the carbon and sulfur cycles, especially considering the high DMS levels (16-32 $\mathrm{mmol} \mathrm{m}^{-2}$ ) associated with Phaeocystis sp. and the percentage of DMSP carbon synthesized relative to total carbon (Stefels and Van Boekel, 1993). In addition, the prevalence of small heterotrophic cells in the open waters and under the ice present in the Barents Sea from late winter through to late summer (Rat'kova and Wassmann, 2002), and the presence of DMSP in these waters at times when autotrophic cells are scarce, are likely to also have an impact on year-round DMSP concentrations.

Apart from shifts in algal species, Hansen et al. (2003) suggest that a reduction in the ice cover in Arctic areas can lead to more subtle structural changes in the food web. For instance, an increased ice-free period can lead to an earlier spring bloom, potentially creating a mismatch between primary production and copepod grazers. The result may be a food web dominated by protozooplankton, resulting in lower export of organic material out of the photic zone despite increased primary productivity, or alternatively lead to changes in species composition or behaviour. As DMSP and DMS extracellular release is sensitive to zooplankton grazing, this scenario is again relevant to net DMS production.

\section{Conclusions}

The significant decrease of sea-ice cover and increase of SST (with the greatest increase in late summer) are the main drivers for the increase in DMS flux by about $85 \%$ under warming. Clearly, the removal of the sea-ice barrier is the principal mechanism for an increase in DMS flux. However, the DMS transfer velocity is sensitive to temperature change, and the increase in SST in late summer also increases the flux from open water. While there is also some shoaling of the mixed layer during spring under warming, the present MLD is already quite shallow and the impact on phytoplankton growth is slight. This contrasts with our analysis in the Antarctic, where a strong decrease in the MLD during spring-summer was the primary factor in the perturbation to DMS flux under warming (Gabric et al., 2003). The sensitivity of both the physical and ecological systems to simulated loss of sea ice is clearly high in the Arctic. Recent analyses of data reveal a high-frequency interannual variability in mean Arctic ice thickness that is dominated by changes in the amount of summer melt, rather than by changes in circulation (Laxon et al., 2003). The current CHL and DMSP field data reveal high interannual variability, which we have previously related to variation in timing and length of the season of sea-ice melting $(\mathrm{Qu}$ et al., in press).

The model results presented here demonstrate that emissions of DMS may clearly be influenced by the loss of summer sea ice; however, the possible change in phytoplankton species in the Arctic as mean sea ice retreats, is also likely to be influential. Although our current database on Arctic sulfur species is limited, the evidence suggests that future phytoplankton species shifts 
may enhance DMS production. The net impact of warming on DMS emissions will depend on complex interactions between the structure and composition of the Arctic food web, the timing of ice melt and the duration of the melt season.

Loss of summer sea ice due to climate warming would result in greater surface warming; and enhanced water vapour release may result in greater condensation on existing airborne $\mathrm{CCN}$. When CCN are abundant, the water droplets present in clouds will be more abundant and smaller and will reflect more sunlight into space, enhancing the cooling effect at the surface compared with when particles are scarce. Summer expeditions to the central Arctic have shown that most CCN come from natural sources, mostly oxidation products of DMS that is released from its precursor DMSP in the uppermost ocean where the planktonic food web is most active (Leck et al., 2002). These submicrometre $\mathrm{CCN}$, however, have now been shown to be aggregates of biogenic particles, such as virus-like solids, organic aggregates, bacteria and fragments of diatoms; these small, organic primary particles were also acting as centres for condensation of the DMS oxidation products (Bigg and Leck, 2001). The changes described above resulting from a tripled equivalent $\mathrm{CO}_{2}$ scenario suggest that in summer in the Arctic a stronger release of DMS, and potentially water vapour, as well as a larger pool of primary biogenic particles, may result in enhanced CCN levels involving a cooling climate feedback and a greater involvement of biological processes.

\section{Acknowledgments}

The authors wish to thank the SeaWiFS Project (code 970.2) and the Distributed Active Archive Centre (code 902) at the Goddard Space Flight Centre, Greenbelt, MD 20771, for the production and distribution of the SeaWiFS data, respectively. These activities are sponsored by NASA's Mission to Planet Earth Program (http://seawifs.gsfc.nasa.gov). The Quikscat/SeaWinds and Advanced Very High Resolution Radiometer data were obtained from the NASA Physical Oceanography Distributed Active Archive Centre at the Jet Propulsion Laboratory/California Institute of Technology (http://podaac.jpl.nasa.gov). The SSMI data were provided by the Defense Meteorological Satellite Program, National Oceanic and Atmospheric Administration, US Department of Commerce (http://www.ncdc.noaa.gov). The NODC (Levitus) World Ocean Atlas 1994 data were provided by the NOAA-CIRES Climate Diagnostics Centre, Boulder, CO (http://www.cdc.noaa.gov/). The World Ocean Atlas 1998 was supplied by the Ocean Climate Laboratory, National Oceanographic Data Centre, National Oceanic and Atmospheric Administration, US Department of Commerce (http://www.nodc.noaa.gov). We are grateful for the efforts of many members of the Climate Modelling and Applications Team who are responsible for the development of CSIRO climate models. We thank Dr David L. Carroll from CU Aerospace for making available the Genetic Algorithm Fortran code. Finally, we gratefully acknowledge the financial assistance of an ASAC Grant from the Australian Antarctic Division and an Australian Research Council Discovery Grant. NSF funding to P.A.M. allowed field sampling of the Barents Sea (OPP-9711723, OPP0084455).

\section{References}

Arashkevich, E., Wassmann, P., Pasternak, A. and Riser, C. W. 2002. Seasonal and spatial changes in biomass, structure, and development progress of the zooplankton community in the Barents Sea. J. Marine Syst. 38(1-2), 125-145.

Ayers, G. P. and Gras, J. L. 1991. Seasonal relationship between cloud condensation nuclei and aerosol methanosulphonate in marine air. Nature 353, 834-835.

Bates, T. S., Lamb, B. K., Guenther, A., Dignon, J. and Stoiber, R. E. 1992. Sulfur emissions to the atmosphere from natural sources. J. Atmos. Chem. 14, 325-337.

Bigg, E. K. and Leck, C. 2001. Properties of the aerosol over the central Arctic Ocean. J. Geophys. Res.-Atmos. 106(D23), 32101-32109.

Bigg, E. K., Leck, C. and Tranvik, L. 2004. Particulates of the surface microlayer of open water in the central Arctic Ocean in summer. Marine Chem. 91(1-4), 131-141.

Bouillon, R. C., Lee, P. A., de Mora, S. J., Levasseur, M. and Lovejoy, C. 2002. Vernal distribution of dimethysulphide, dimethysulphoniopropionate, and dimethylsulphoxide in the North Water in 1998. Deep-Sea Res. Pt II 49, 5171-5189.

Charlson, R. J., Lovelock, J. E., Andreae, M. O. and Warren, S. G. 1987. Oceanic phytoplankton, atmospheric sulphur, cloud albedo and climate. Nature 326, 655-661.

Charlson, R. J., Schwartz, S. E., Hales, J. M., Cess, R. D., Coakley, J. A. and co-authors. 1992. Climate forcing by anthropogenic aerosols. Science 255(5043): 423-430.

Comiso, J. C. and Parkinson, C. L. 2004. Satellite-observed changes in the Arctic. Phys. Today 57(8), 38-44.

Cox, M. D., 1984. A Primitive Equation, 3-Dimensional Model of the Ocean, GFDL Ocean Group Technical Report no. 1. GFDL/Princeton University, Princeton, NJ.

Cropp, R. 2003. A Biogeochemical Modelling Analysis of the Potential for Marine Ecosystems to Regulate Climate by the Production of Dimethylsulphide. PhD Thesis. Griffith University, Nathan, Queensland.

Curran, M. A. J. and Jones, G. B. 2000. Dimethyl sulfide in the Southern Ocean: seasonality and flux. J. Geophys. Res. 105(D16), $20451-$ 20459.

Curry, J. A. 1995. Interactions among aerosols, clouds, and climate of the Arctic Ocean. Sci. Total Environ. 161, 777-791.

Dong, X. Q. and Mace, G. G. 2003. Arctic stratus cloud properties and radiative forcing derived from ground-based data collected at Barrow, Alaska. J. Climate 6(14), 445-461.

Eppley, R. W. 1972. Temperature and phytoplankton growth in the sea. Fish. Bull. 70, 1063-1085.

Flato, G. M. 2004. Sea-ice and its response to $\mathrm{CO}_{2}$ forcing as simulated by global climate models. Clim. Dynam. 23(3-4), 229-241.

Gabric, A. J., Ayers, G. P. and Sander, G. C. 1995. Independent marine and atmospheric model estimates of the sea-air flux of dimethylsulfide in the Southern Ocean. Geophys. Res. Lett. 6(14), 3521-3524. 
Gabric, A. J., Cropp, R., Hirst, A. and Marchant, H. 2003. The sensitivity of dimethylsulphide production to simulated climate change in the eastern Antarctic Southern Ocean. Tellus 55B, 966-981.

Gabric, A. J., Matrai, P. and Vernet, M. 1999. Modelling the production of dimethylsulphide during the vernal bloom in the Barents Sea. Tellus 51B, 919-938.

Gabric, A. J., Murray, C. N., Stone, L. and Kohl, M. 1993. Modeling the production of dimethylsulphide during a phytoplankton bloom. J. Geophys. Res. 98(C12), 22 805-22 816.

Gabric, A. J., Simo, R., Cropp, R. A., Hirst, A. C. and Dachs, J. 2004. Modeling estimates of the global emission of dimethylsulfide under enhanced greenhouse conditions. Global Biogeochem. Cycles 6(14), B2014-B2014.

Gabric, A. J., Whetton, P., Boers, R. and Ayers, G. P. 1998. The impact of GCM predicted climate change on the air-to-sea flux of dimethylsulphide in the subantarctic Southern Ocean. Tellus 50B, 388-399.

Gordon, H. G. and O'Farrell, S. P. 1997. Transient climate change in the CSIRO coupled model with dynamic sea ice. Mon. Weather Rev. 125, 875-907.

Hansen, B., Christiansen, S. and Pedersen, G. 1996. Plankton dynamics in the marginal ice zone of the central Barents Sea during spring: carbon flow and structure of the grazer chain. Polar Biol. 16, 115128.

Hansen, A. S., Nielsen, T. G., Levinsen, H., Madsen, S. D., Thingstad, T. F. and co-author 2003. Impact of changing ice cover on pelagic productivity and food web structure in Disko Bay, West Greenland: a dynamic model approach. Deep-Sea Res. Pt I 6(14), 171-187.

Haywood, J. and Boucher, O. 2000. Estimates of the direct and indirect radiative forcing due to tropospheric aerosols: a review. Rev. Geophys. 6(14), 513-543.

Hirst, A. C., O'Farrell, S. P. and Gordon, H. B. 2000. Comparison of a coupled ocean-atmosphere model with and without oceanic eddyinduced advection. Part I: Ocean spinup and control integrations. J. Climate 13, 139-163.

Holland, J. H. 1975. Adaptation in Natural and Artificial Systems, University of Michigan Press, Ann Arbor, MI.

Houghton, J. T., Meira Filho, L. G., Callander, B. A., Harris, N., Kattenberg, A. and co-editor (ed.) 1996. Climate change 1995: Contribution of Working Group 1 to the Second Assessment Report of the IPCC. Cambridge University Press, Cambridge.

Houghton, J. T., Ding, Y., Griggs, D. J., Noguer, M., Linden, P. J. V. D. and co-editor (ed.) 2001. Climate Change 2001: The Scientific Basis. Contribution of Working Group I to the Third Assessment Report of the Intergovernmental Panel on Climate Change (IPCC), Cambridge University Press, Cambridge.

Johannssen, O. M., Bengtsson, L., Miles, M. W., Kuzmina, S. I., Semenov, V. A. and co-authors 2004. Arctic climate change: observed and modelled temperature and sea-ice variability. Tellus 56A, 328341.

Kattenberg, A., Giorgi, F., Grassl, H., Meehl, G. A., Mitchell, F. B. and co-authors 1996. Climate models-projections of future climate. In: Climate Change 1995: The Science of Climate Change (eds J. T. Houghton and co-editors). Cambridge University Press, Cambridge, 285-357.

Keller, M. D., Bellows, W. K. and Guillard, R. L. 1989. Dimethyl Sulfide production in marine phytoplankton. In: Biogenic Sulfur in the Environment (eds E. S. Saltzman and W. J. Cooper). American Chemical Society, Washington, DC, 183-200.
Kettle, A. and Andreae, M. O. 2000. Flux of dimethylsulfide from the oceans: a comparison of updated data sets and flux models. J. Geophys. Res. 105(D22), 26793-26808.

Kettle, A. J., Andreae, M. O., Amouroux, D., Andreae, T. W., Bates, T. S. and co-authors 1999. A global database of sea surface dimethylsulfide (DMS) measurements and a procedure to predict sea surface DMS as a function of latitude, longitude and month. Global Biogeochem. Cycles 13, 399-444.

Kirst, G. O., Thiel, C., Wolff, H., Nothnagel, J., Wanzek, M. and co-author 1991. Dimethylsulfoniopropionate (DMSP) in ice algae and its possible biological role. Mar. Chem. 35, 381-388.

Lawrence, M. G. 1993. An empirical-analysis of the strength of the phytoplankton dimethylsulfide-cloud-climate feedback cycle. J. Geophysics. Res.-Atm. 98(D11), 20 663-20673.

Laxon, S., Peacock, N. and Smith, D. 2003. High interannual variability of sea ice thickness in the Arctic region. Nature 6(14), 947-950.

Leck, C. and Bigg, E. K. 1999. Aerosol production over remote marine areas-a new route. Geophys. Res. Lett. 26(23), 3577-3580.

Leck, C., Bigg, E. K., Covert, D. S., Heintzenberg, J., Maenhaut, W. and co-authors 1996. Overview of the atmospheric research programme during the International Arctic Ocean Expedition of 1991 (IAOE-91) and its scientific results. Tellus 48B, 136-155.

Leck, C., Norman, M., Bigg, E. K. and Hillamo, R. 2002. Chemical composition and sources of the high Arctic aerosol relevant for cloud formation. J. Geophys. Res. 107(D12), AAC1-1-17.

Leck, C. and Persson, C. 1996a. The central Arctic Ocean as a source of dimethyl sulfide—-seasonal variability in relation to biological activity. Tellus 48B, 156-177.

Leck, C. and Persson, C. 1996b. Seasonal and short-term variability in dimethyl sulfide, sulfur dioxide and biogenic sulfur and sea salt aerosol particles in the arctic marine boundary layer during summer and autumn. Tellus 48B, 272-299.

Leck, C., Tjernström, M., Matrai, P., Swietlicki, E. and Bigg, K. 2004. Can marine microorganisms influence melting of the Arctic pack ice? EOS, Trans. Am. Geophys. Union 85(3), 25.

Levasseur, M., Gosselin, M. and Michaud, S. 1994. A new source of dimethyl sulfide for the Arctic atmosphere: ice diatoms. Mar. Biol. 121, 381-387.

Liss, P. S., Hatton, A. D., Malin, G., Nightingale, P. D. and Turner, S. M. 1997. Marine sulphur emissions. Phil Trans. R. Soc Lond. B. Biol. Sci. 352, 159-169.

Liss, P. S. and Merlivat, L., 1986. Air-sea gas exchange rates: Introduction and synthesis. In: The Role of Air-Sea Exchange in Geochemical Cycling (ed. P. Buat-Menard). Reidel, Hingham, MA, 113-127.

Matrai, P. A. and Keller, M. D. 1993. Dimethylsulfide in a large-scale coccolithophore bloom in the Gulf of Maine. Cont. Shelf Res. 13, 831-843.

Matrai, P. A. and Vernet, M. 1997. Dynamics of the vernal bloom in the marginal ice-zone of the Barents Sea: dimethyl sulfide and dimethylsulfoniopropionate budgets. J. Geophys Res. 102, 22 965-22 979.

Merico, A., Tyrrell, T., Brown, C. W., Groom, S. B. and Miller, P. I. 2003. Analysis of satellite imagery for Emiliania huxleyi blooms in the Bering Sea before 1997. Geophys. Res. Lett. 30(6), 1337, doi:101029/2002GL016648.

Nightingale, P. D., Malin, G., Law, C. S., Watson, A. J., Liss, P. S. and co-authors 2000. In situ evaluation of air-sea gas exchange parameterizations using novel conservative and volatile tracers. Global Biogeochem. Cycles 6(14), 373-387. 
Nilsson, E. D., Rannik, U., Swietlicki, E., Leck, C., Aalto, P. P. and co-authors 2001. Turbulent aerosol fluxes over the Arctic Ocean 2. Wind-driven sources from the sea. J. Geophys. Res.-Atm. 106(D23), 32 139-32 154.

O'Dwyer, J., Isaksson, E., Vinje, T., Jauhiainen, T., Moore, J. and co-authors 2000. Methanesulfonic acid in a Svalbard ice core as an indicator of ocean climate. Geophys. Res. Lett. 6(14), 1159-1162.

O'Farrell, S. P. 1997. Sensitivity study of a dynamical sea ice model. The effect of external stresses and land boundary conditions on ice thickness distribution. J. Geophys. Res. 103, 15 751-15 782.

Olli, K., Wexels Riser, C., Wassmann, P., Ratkova, T., Arashkevich, E. and co-author 2002. Seasonal variation in vertical flux of biogenic matter in the marginal ice zone and the central Barents Sea. J. Marine Syst. 38(1-2), 189-204.

Pandis, S. N., Russell, L. M. and Seinfeld, J. H. 1994. The relationship between DMS flux and CCN concentration in remote marine regions. J. Geophys. Res.-Atm. 99(D8), 16945-16957.

Parkinson, C. L. and Cavalieri, D. J. 2002. A 21 year record of Arctic sea-ice extents and their regional, seasonal and monthly variability and trends. Ann. Glaciol. 34, 441-446.

Press, W. H., Teukolsky, S. A., Vetterling, W. T. and Flannery, B. P. 1992. Numerical Recipes in FORTRAN: the Art of Scientific Computing. Cambridge University Press, Cambridge.

Qu, B., Gabric, A. J. and Matrai, P. A. Spatial and temporal distribution of chlorophyll-a and its relation to ice cover, radiation and sea surface temperature in the Barents Sea. Polar Biol. in press.

Quinn, P. K., Miller, T. L., Bates, T. S., Ogren, J. A., Andrews, E. and co-author 2002. A 3-year record of simultaneously measured aerosol chemical and optical properties at Barrow, Alaska. J. Geophys. Res.Atm. 107(D11), 4130, doi:10.1029/2001JD001248.

Rat'kova, T. N. and Wassmann, P. 2002. Seasonal variation and spatial distribution of phyto- and protozooplankton in the central Barents Sea. J. Marine Syst. 38(1-2), 47-75.

Reigstad, M., Wassmann, P., Wexels Riser, C., Oygarden, S. and Rey, F. 2002. Variations in hydrography, nutrients and chlorophyll a in the marginal ice-zone and the central Barents Sea. J. Marine Syst. 38(1-2), 9-29.

Saltzman, E. S., King, D. B., Holmen, K. and Leck, C. 1993. Experimental determination of the diffusion coefficient of dimethylsulfide in water. J. Geophys. Res. 98, 16481-16486.

Serreze, M. C., Walsh, J. E., Chapin, F. S., Osterkamp, T., Dyurgerov, M. and co-authors 2000. Observational evidence of recent change in the northern high-latitude environment. Climatic Change 46(1-2), 159-207.

Simó, R. 2001. Production of atmospheric sulfur by oceanic plankton: biogeochemical, ecological and evolutionary links. Trends Ecol. Evol. 16, 287-294

Simó, R. and Pedrós-Alió, C. 1999. Short-term variability in the open ocean cycle of dimethylsulfide. Global Biogeochem. Cycles 13(4), $1173-1181$.

Slagstad, D. and Wassmann, P. 1997. Climate change and carbon flux in the Barents Sea: 3-D simulations of ice-distribution, primary production and vertical export of particulate organic matter. Mem. Natl. Inst. Polar Res. 51 (Special Issue), 119-141.

Smyth, T. J., Tyrrell, T. and Tarrant, B. 2004. Time series of coccolithophore activity in the Barents Sea, from twenty years of satellite imagery. Geophys. Res. Lett. 6(14), L11302, doi:10.1029/ 2004GL019735.

Stefels, J. and Van Boekel, W. H. M. 1993. Production of DMS from dissolved DMSP in axenic cultures of the marine phytoplankton species P. pouchetii. Mar. Ecol. Prog. Ser. 97, 1118.

Sunda, W., Kieber, D. J., Kiene, R. P. and Huntsman, S. 2002. An antioxidant function for DMSP and DMS in marine algae. Nature 418(6895), 317-320.

Talling, J. F. 1957. Photosynthetic characteristics of some freshwater plankton diatoms in relation to underwater radiation. New Phytol. 56, 29-50.

Treffeisen, R., Herber, A., Ström, J., Shiobara, M., Yamagata, T. Y. and co-authors 2004. Interpretation of Arctic aerosol properties using cluster analysis applied to observations in the Svalbard area. Tellus 56B, 457-476.

Trevena, A. J., Jones, G. B., Wright, S. W. and van den Enden, R. 2003. Profiles of dimethylsulphoniopropionate (DMSP), algal pigments, nutrients, and salinity in the fast ice of Prydz Bay, Antarctica. J. Geophys. Res. 108, 2-11.

Tschudi, M. A., Curry, J. A. and Maslanik, J. A. 2001. Airborne observations of summertime surface features and their effect on surface albedo during FIRE/SHEBA. J. Geophys. Res.-Atm. 106(D14), $15335-15344$.

Verity, P. G., Wassmann, P., Frischer, M. E., Howard-Jones, M. H. and Allen, A. E. 2002. Grazing of phytoplankton by microzooplankton in the Barents Sea during early summer. J. Marine Syst. 38(1-2), 109123. 